\title{
Könyvszemle
}

SIPOS JÚLIA GONDOZÁSÁBAN

\section{VÍRUSVADÁSZAT: IZGALMAS KRIMI, ELGONDOLKODTATÓ BESZÉLGETÉSEK ÉS LEHANGOLÓ KONZEKVENCIÁK}

Régen olvastam olyan könyvet, amely annyira le tudott kötni, mint Barát József Kemenesi Gáborral írott könyve. Igazán kár, hogy doku, nem fantasy. Sajnos fel sem merül, hogy ki játssza majd a főszerepeket a Netflix vagy az HBO megfilmesített verziójában. Ez a könyv az elmúlt két, többé-kevésbé elvesztegetett évünk történéseit elemzi egy újságíró és partnere, egy „vírusvadász” szemszögéből. Bár a világ még a sebeit nyalogatja az elszenvedett csapások után, a leírtakból világosan kiderül, hogy nem lehetünk elég hálásak a sorsnak, hogy egyelöre megúsztuk ennyivel.

A Virusvadászat címü könyv részben a járvány kialakulásának, emlékezetesebb történéseinek tárgyilagos leírását tartalmazza. Rendkívül izgalmas. Bejárja a bolygó számos országát, rávilágít a helyi sajátságokra, intézkedésekre, helyenként azok politikai hátterére is, még egy sikeres politikus portréjával is megismerkedünk. Ezzel párhuzamosan tanúi vagyunk a beszélgetéseknek az újságíró és a vírusvadász között. Lépésről lépésre bontakozik ki előttünk egy rendkívül rokonszenves kutató egyénisége, aki - bár a tudománynak egy elképesztően szük területére szakosodott, globális ismeretei vannak - kivételesen precíz tünetegyüttest állít fel a világot fenyegető veszedelmekről. A járvány nyomán botcsinálta szakértők serege tünt fel a médiában, néha tudatosan növelve az átlagember fejében kialakult ismereti káoszt. Kijelentéseik hol tehetetlen dühöt, hol harsány nevetést váltottak ki belölem. Ezzel szemben - bár két generáció választ el Kemenesi Gábortól - minden, a könyvben leírt gondolatával száz százalékig egyet tudok érteni! A könyvből világos összefüggések bontakoznak ki a denevérek és kisrágcsálók életterét elhódító agresszív emberi tevékenység, az egzotikus vadállatokat luxusból felzabáló ,tehetősek” és a kibontakozó éghajlati katasztrófa között. A jelenlegi halálos járvány csak egy kis ízelítő abból, amit várhatunk, ha továbbra is leigázni akarjuk a természetet ahelyett, hogy megpróbálnánk együtt élni vele.

Végigkövethetjük, hogyan lett képes a frászt ráhozni az önelégült, high tech 21. század szuperhatalmaira egy alapjában véve kevéssé ártalmas náthavírus, hogyan tudta hathatós emberi segítséggel kialakítani az elmúlt száz év legpusztí- 
tóbb pandémiáját. Fejcsóválva olvashatjuk, mennyi emberi felelőtlenség, mennyi ostobaság, mennyi rövidlátó politikusi baklövés segítette a vírust pusztító hullámai során. A más országokban elkövetett, égbekiáltóan hibás döntések mellett megjelenik a hazai járványkezelés hibáinak tapintatos, de egyértelmü kritikája is. Viszonylag keveset foglalkozik a könyv a vírus fáradhatatlan szövetségeseivel, az internet bugyraiban fermentálódó égbekiáltó ostobaságok kiagyalóival és a felelőtlenül hatásvadász vagy tudományellenes médiaszereplők okozta tetemes károkkal.

A lakosság legműveletlenebb rétegei, az öntudatos ostobák és a fészbukmétely által megtévesztett okoskodók túszul ejtették a társadalmat. Az élet megbénításával fenyegetőznek, ha a népszerüséghajhász politikusok mégis megtennék, amit tenniük kellene, de amit nincs merszük megtenni. Intézkedéseket kellene foganatosítani, melyek megvédenék az emberek életét. De a gyeplő a lovak között, nem érheti hátrány az antiszociális beoltatlanokat, még a gyermekeket sem kötelező beoltani egy potenciálisan halálos betegség ellen.

Amikor letesszük a könyvet, és meghallgatjuk az esti híradót, rádöbbenünk, hogy az emberiség semmit sem tanult a leckéből. Ha már az oltást nem is lehet, legalább e könyv elolvasását kötelezővé kellene tenni.

(Barát József-Kemenesi Gábor: Virusvadászat. A SARS-CoV-2 regénye. Budapest: Cser Kiadó, 2021, 248 o.)

Duda Ernő

immunológus, professor emeritus 